\title{
Financeirização, mercantilização e reestruturação espaço-temporal: reflexões a partir do enfoque dos ciclos sistêmicos de acumulação e da teoria do duplo movimento
}

\author{
Financialization, commodification and space-time \\ restructuring: reflections from the systemic cycles \\ of accumulation approach and the theory of double movement
}

Luiz César de Queiroz Ribeiro Nelson Diniz

\section{Resumo}

Pretendemos, com este artigo, refletir sobre as relações entre financeirização e mercantilização. 0 principal objetivo desta pesquisa é encontrar marcos teóricos para a compreensão do atual ciclo de reestruturação espaço-temporal a partir das teorias do sistema-mundo capitalista e da economia política das relações internacionais. Nossa exposição possui dois objetivos. Primeiro, posicionaremo-nos, a partir das perspectivas braudeliana e polanyiana, nos debates sobre os sentidos atribuídos à financeirização e à mercantilização. Em seguida, ilustraremos, com alguns exemplos, como essas perspectivas sugerem a construção de novos olhares sobre fenômenos que estão no centro das investigações no campo dos estudos urbanos e territoriais.

Palavras-chave: financeirização; mercantilização; ciclos sistêmicos de acumulação; duplo movimento.

\begin{abstract}
We intend, with the present article, to reflect on the relations between financialization and commodification. The main objective of this research is to find theoretical frameworks for the understanding of the current cycle of space-time restructuring based on the theories of the capitalist world-system and of the political economy of international relations. Our exposition has two objectives. First, we will position ourselves, from a Braudelian and Polanyian perspective, in the debates about the meanings attributed to financialization and commodification. Next, we will illustrate, with some examples, how these perspectives suggest the construction of new views on phenomena that are at the center of investigations in the field of urban and territorial studies.
\end{abstract}

Keywords: financialization; commodification; systemic cycles of accumulation; double movement. 


\section{Introdução}

Pretendemos, com o presente artigo, refletir sobre as relações entre financeirização e mercantilização, considerados os impactos urbanos e territoriais desses processos inter-relacionados. Ao fazê-lo, apresentaremos algumas das hipóteses da pesquisa "Metrópole, Capital e Estado", desenvolvida no âmbito do Observatório das Metrópoles. Em linhas gerais, o principal objetivo dessa pesquisa é encontrar marcos teóricos para a compreensão do atual ciclo de reestruturação espaço-temporal a partir das teorias do sistema-mundo capitalista e das teorias da economia política das relações internacionais, fundadas numa matriz braudeliana.

Em nossa opinião, as justificativas imediatas para uma reflexão dessa natureza podem ser deduzidas do próprio tema do seminário para o qual foi originalmente elaborada: "Crisis mundial y financiarización: impactos urbanos y territoriales". ${ }^{1}$ Como se sabe, as mudanças urbanas e territoriais típicas da atual fase de desenvolvimento do capitalismo expressam, cada vez mais, uma lógica geral de produção social do espaço que está determinada pelas novas formas de acumulação financeirizada. Sem dúvida, essas formas manifestaram, explicita e abertamente, seus efeitos mais contraditórios desde o início da última grande crise sistêmica do capitalismo, ainda em curso. ${ }^{2}$

Pois bem, organizaremos nossa exposição em torno de dois objetivos básicos. Em primeiro lugar, pretendemos nos posicionar, a partir de uma perspectiva braudeliana e polanyiana, nos debates sobre os diferentes sentidos atribuídos à financeirização e à mercantilização. Desse modo, buscamos contribuir para uma melhor definição dos limites teóricos entre esses dois conceitos fundamentais. Em seguida, procuramos ilustrar, com alguns exemplos, de que maneira essas leituras particulares sugerem a possibilidade de construção de um novo olhar sobre fenômenos e objetos que estão no centro das investigações no campo dos estudos urbanos e territoriais.

\section{0 que é financeirização?}

É comum iniciar o debate sobre o significado da financeirização contemporânea do capitalismo enfatizando sua forma de manifestação mais aparente. Sendo assim, podemos afirmar, em consonância com Braga (1997), que esse processo se refere, antes de tudo, à "crescente e recorrente defasagem, por prazos longos, entre os valores dos papéis representativos da riqueza [...] e os valores dos bens, serviços e bases técnico-produtivas em que se fundam a reprodução da vida e da sociedade" (p. 196). 0 Quadro 1 permite ilustrar essa tendência atual por intermédio da comparação entre o crescimento do estoque de ativos financeiros e o do PNB mundiais.

É evidente que a identificação da defasagem entre 0 valor dos ativos financeiros $e$ o dos bens e serviços não é, de modo algum, suficiente para definir com precisão o processo em tela. Não obstante, os dados acima indicam que, mesmo após a crise sistêmica de acumulação iniciada em 2007-2008, mantiveram-se as projeções de crescimento da desproporção entre esses valores. Portanto, ainda de acordo com Braga (1997), tomamos como um ponto de partida mais consistente a ideia segundo a 
Quadro 1 - Riqueza fictícia e renda real

\begin{tabular}{|c|c|c|c|}
\hline Ano & $\begin{array}{c}\text { Estoque mundial de ativos } \\
\text { financeiros* (US\$ trilhões) }\end{array}$ & $\begin{array}{c}\text { PNB mundial } \\
\text { (US\$ trilhões) }\end{array}$ & $\begin{array}{c}\text { Relação estoque ativos } \\
\text { financeiros/PNB }\end{array}$ \\
\hline 1980 & 12 & 11,8 & 1,02 \\
1993 & 53 & 24,9 & 2,13 \\
1996 & 69 & 30,3 & 2,28 \\
1999 & 96 & 31,1 & 3,09 \\
2003 & 118 & 37,1 & 3,18 \\
2006 & 167 & 48,8 & 3,42 \\
2007 & $200^{* *}$ & 54,8 & 3,65 \\
$2010^{* * *}$ & 209 & 55,9 & 3,74 \\
\hline
\end{tabular}

* Inclui ações e debêntures, títulos de dívida privados e públicos e aplicações bancárias; não inclui derivativos.

** Estimativas. ${ }^{* * *}$ Projeções.

Fonte: Elaborado por Paulani (2009) a partir de dados do McKinseys Global Institute (ativos) e do FMI (PNB).

qual a financeirização deve ser compreendida como o padrão sistêmico de riqueza do capitalismo contemporâneo. Quer dizer, como um processo geral de transformação do capitalismo que se torna estrutural, cria novas formas institucionais, marca as estratégias de todos os agentes privados relevantes, altera a operação das finanças e dos gastos públicos e, de alguma maneira, diferencia-se dos modos de manifestação do capital enquanto expressão do valor-trabalho.

Com efeito, são muito variadas as formas de explicar e enunciar as características, as causas e as consequências da denominada financeirização. Dentre elas, destacamos, por exemplo:

a) a releitura das reflexões de Marx (1986) sobre o capital portador de juros e o capital fictício, assim como de suas teorias da renda;

b) a retomada das teorias sobre 0 advento e as relações entre 0 imperialismo e o capital financeiro, na passagem do século XIX ao XX.
Teorias desenvolvidas, principalmente, por autores clássicos do marxismo, como Hilferding (1986), Bukharin (1986) e Lenin (1977);

c) o resgate das teorias do capitalismo monopolista, que consolidaram e ampliaram as formulações dos clássicos do marxismo e que se referem, por exemplo, às elaborações seminais de Magdoff e Sweezy (1987);

d) as abordagens que buscam compreender as relações entre as crises de sobreacumulação de capitais e a produção social do espaço. Sem dúvida, Lefebvre (2008) e Harvey (2015) são seus principais expoentes;

e) as teses e teorias sobre o surgimento do regime de acumulação financeirizado ou com dominância financeira, elaboradas por autores tais como Aglietta (1998) e Boyer (2000). Em nossa opinião, essas teses e teorias se tornaram as formas mais difundidas de compreensão crítica da financeirização contemporânea, sobretudo na versão formulada por Chesnais (2002); 
f) a hipótese da instabilidade financeira do capitalismo, de matriz pós-keynesiana, desenvolvida por autores como Minsky (1982), e que expressam a renovação e a atualização da Teoria Geral do Emprego, do Juro e da Moeda de Keynes (1986);

g) as distintas perspectivas que denominamos, provisoriamente, sociologia econômica e/ou geografia econômica da acumulação financeirizada. Sublinhamos, por exemplo, as reflexões de: 1) Lapavitsas (2009), sobre as novas formas de expropriação financeira; 2) García-Lamarca e Kaika (2016), sobre a biopolítica do endividamento hipotecário; e 3) Bauman (2010), sobre a vida à crédito;

h) as teorias do sistema-mundo capitalista e as teorias da economia política das relações internacionais, de viés braudeliano, cujos principais representantes são Wallerstein (2011), Arrighi (2003) e Fiori (2014). Ressaltamos, principalmente, a concepção dos ciclos sistêmicos de acumulação, apresentada por Giovanni Arrighi em seu clássico $O$ longo século $X X$ : dinheiro, poder e as origens do nosso tempo.

Sem deixar de dialogar com as demais abordagens, tomamos como referência fundamental a concepção dos ciclos sistêmicos de acumulação. Desse modo, tal como Arrighi (2003), acreditamos que é possível buscar formas de compreensão das atuais transformações do capitalismo "à luz de padrões de repetição e evolução que abarcam todo o curso do capitalismo histórico como sistema mundial" (p. 4). Para nós, ainda em consonância com Arrighi (ibid.), a ampliação dos horizontes de referência espaço-temporais permite revelar como "tendências que pareciam inéditas e imprevisíveis começam a afigurar-se familiares".
Dito de outra maneira, buscamos relativizar ou mesmo superar as interpretações que enfatizam, excessivamente, as mudanças contemporâneas do capitalismo.

\section{Tempo, espaço e capitalismo na perspectiva braudeliana}

Como já mencionado, a concepção dos ciclos sistêmicos de acumulação está fundada no pensamento de Fernand Braudel, particularmente nas suas formas de conceber o papel do tempo e do espaço na explicação dos processos sociais e em sua descrição singular das características gerais do capitalismo. Portanto, antes de nos referirmos sistematicamente a essa concepção, apresentaremos alguns elementos de sua fundamentação teórico-metodológica.

\section{A injeção de história na economia}

Em sua exposição sobre as posturas metodológicas estabelecidas por Braudel, Cecilio (2012) destaca, em primeiro lugar, o que denomina "injeção de história na economia". Ao fazê-lo, aponta dois "méritos" principais na abordagem histórico-social de matriz braudeliana. De um lado, ela permitiria identificar padrões de recorrência típicos de toda a história do capitalismo e fundamentais para a compreensão do mundo contemporâneo. ${ }^{3}$ De outro, seria um contraponto aos distintos modos de elaboração de leis sociais abstratas e universalmente válidas, sobretudo as produzidas no campo das ciências econômicas. ${ }^{4}$ 
De acordo com Wallerstein (2006), no que diz respeito à concepção do tempo, Braudel travou uma "batalha" teórico-metodológica em duas frentes, isto é, "contra as duas posições nominalmente antitéticas que vêm dominando o pensamento social desde pelos menos a metade do século XIX, as epistemologias ideográfica e nomotética" (p. 161). A perspectiva ideográfica é a que se concentra em datar acontecimentos para obter "uma cronologia e, por conseguinte, uma narrativa, um relato, uma história que é peculiar e explicável somente em seus próprios termos" (ibid.). A perspectiva nomotética, por sua vez, ao pretender distinguir padrões universais do comportamento humano, torna o tempo histórico irrelevante. Em seus esforços de superação simultânea das epistemologias ideográfica e nomotética, Braudel (1990) recorreu à construção de uma tipologia diferencial dos tempos histórico-sociais. Para tanto, ainda segundo Wallerstein (2006), sublinhou a importância dos ritmos cíclicos e das estruturas duradouras, em detrimento do tempo breve da história dos acontecimentos.

Braudel (1990) não defendeu que os historiadores e cientistas sociais abandonassem por completo o tempo dos acontecimentos, "a mais caprichosa, a mais enganadora das durações" (p. 11). Não obstante, sugeriu "sair-se dele para voltar a ele mais tarde, mas com outros olhos, carregados com outras inquietações, com outras perguntas" (ibid., p. 17). Em sua perspectiva, todo trabalho histórico decompõe o tempo passado de acordo com preferências e exclusões. A história tradicional, por exemplo, privilegiou a narrativa atenta ao tempo breve, "à medida dos indivíduos, da vida cotidiana, das nossas ilusões, das nossas rápidas tomadas de consciência" (ibid., p. 11). Por seu turno, a história econômica e social salientou a oscilação cíclica e sua duração. Trata-se do recitativo da conjuntura, que investiga o passado o dividindo em amplas seções. Acima do recitativo da conjuntura, encontrar-se-ia "uma história de fôlego ainda mais contido e, nesse caso, de amplitude secular: trata-se da história de longa, e mesmo de muito longa, duração" (ibid., p. 10). Nos termos de Braudel (ibid.), considerar a longa duração significa reconhecer que todas as possíveis escalas e fragmentações do tempo devem ser compreendidas a partir da "profundidade" e das "estruturas" em torno das quais gravitam. Isto é, envolve "familiarizar-se com um tempo que se tornou mais lento, por vezes, até quase ao limite da mobilidade" (p. 17).

Portanto, apesar de conceber a "existência de dezenas e até centenas de tempos na história" (Rojas, 2013, p. 21), Braudel elaborou sua proposta metodológica das temporalidades diferenciais a partir da "tripla esquematização do tempo dos acontecimentos ou tempo da curta duração, tempo das conjunturas ou tempo médio e tempo longo das estruturas, 0 tempo da longa duração histórica" (ibid.). Para Rojas, a concepção braudeliana das temporalidades diferenciais conduz à desconstrução da visão moderna do tempo. Quer dizer, em oposição ao tempo linear, plano e unitário, Braudel elaborou uma "nova teoria da decomposição e diferenciação temporal" (ibid., p. 23) - teoria fundada em "tempos e durações de densidade e intensidade diferençadas, hierarquizados, entre os quais o mais importante é a longa duração" (ibid.). 


\section{0 espaço-tempo ampliado: da economia-mundo europeia à economia mundial capitalista}

Braudel definiu sua investigação da história de longa duração do capitalismo, entre os séculos XV e XVIII, como uma tentativa de "vincular o capitalismo, sua evolução e seus meios a uma história geral do mundo" (Braudel, 1987, p. 30). Para tanto, discerniu uma unidade que se afirmou progressivamente sobre a existência de todas as economias. Para explicar o processo de constituição da sociedade mundial hierarquizada, estabeleceu a distinção entre economia mundial e economia-mundo. ${ }^{5}$

As economias-mundos são definidas a partir de três aspectos básicos: 1) ocupam um espaço geográfico determinado, ainda que potencialmente suscetível a rupturas; 2 ) organizam-se em torno de um centro ou núcleo, um polo representado por uma cidade dominante; e 3) dividem-se em zonas sucessivas: o centro, as zonas intermediárias e as margens. Considerada a organização hierárquica da sociedade mundial, essas zonas concêntricas são progressivamente desfavorecidas à medida que se distanciam do núcleo - locus dos preços e salários altos, das indústrias lucrativas, do desenvolvimento técnico-científico e do afluxo de metais preciosos, de moedas e de títulos de crédito. ${ }^{6}$

Pois bem, a partir da ampliação das escalas espaço-temporais de explicação dos processos sociais, Braudel (ibid.) demonstrou como a economia-mundo europeia constituiu-se na matriz do capitalismo e da economia mundiais. Para reconstruir essa trajetória, enfatizou movimentos de centragem, descentragem e recentragem. Isto é, concentrações e deslocamentos de poder realizados no curso de conflitos, tensões e crises econômicas.

Até aproximadamente 1750, os centros dominantes da economia-mundo europeia foram cidades ou cidades-Estados: sucessivamente, Veneza, Antuérpia, Gênova e Amsterdam. A partir de então, criações e dominações urbanas foram substituídas pela dominação nacional. Quando o centro da economia-mundo europeia se deslocou para Londres, a Inglaterra já era uma economia nacional, ou seja, "um espaço político transformado pelo Estado, em virtude de necessidades e inovações da vida material, num espaço econômico coerente, unificado, cujas atividades podiam encaminhar-se em conjunto numa mesma direção" (ibid., p. 36). A ascensão de Londres, assim como a transformação da Inglaterra em economia nacional unificada, inaugurou uma nova etapa da história do capitalismo.

Braudel (ibid.) observa que a Revolução Industrial inglesa foi decisiva no deslocamento do centro da economia-mundo europeia, no século XVIII, de Amsterdam para Londres. No entanto, ao contrário do que sugere o termo "revolução", tratou-se de fenômeno lento e de determinações profundas. Seja como for, a partir desse momento, a economia-mundo europeia tornou-se, progressivamente, economia mundial capitalista, baseada na formação de monopólios de direito ou de fato e na exploração dos recursos do mundo inteiro.

0 processo de centragem, descentragem e recentragem da economia-mundo europeia, em benefício de Londres, assim como a transformação da Inglaterra num espaço político e econômico coerente, já indicam alguns dos traços da concepção braudeliana do capitalismo. Sugerem, acima de tudo, uma dialética entre 
poderes capitalistas e poderes territoriais. A dialética entre Estado e capital será retomada mais adiante. Antes disso, é preciso destacar de que maneira, segundo essa concepção, a flexibilidade, o ecletismo e a liberdade de escolha são considerados características fundamentais da reprodução do capitalismo histórico como sistema mundial.

\section{A unidade do capitalismo: flexibilidade, ecletismo e liberdade de escolha}

À semelhança do que fez com os tempos histórico-sociais, Braudel também criou um esquema conceitual tripartido para definir as características gerais do capitalismo. Conforme esse esquema, representado na Figura 1, a vida econômica é dividida em três camadas que correspondem às estruturas da vida ou da civilização material, da economia de mercado e do capitalismo.

Pois bem, tal como sugerido pela observação da Figura 1, as camadas nas quais a vida econômica é dividida constituem uma hierarquia. Na base dessa hierarquia está a camada da vida material, quer dizer, a esfera da reprodução social cotidiana, organizada, prioritariamente, em torno da lógica do valor de uso. ${ }^{7}$ Acima dessa camada, ergue-se a economia de mercado, uma esfera de trocas e comunicações horizontais reguladas de maneira mais ou menos automática pela lógica da demanda, da oferta e dos preços. No topo, a camada do capitalismo ou do antimercado consiste numa esfera de circulação diferenciada, caracterizada, sobretudo, pela não especialização, pela

Figura 1 - Representação do esquema tripartido da vida econômica

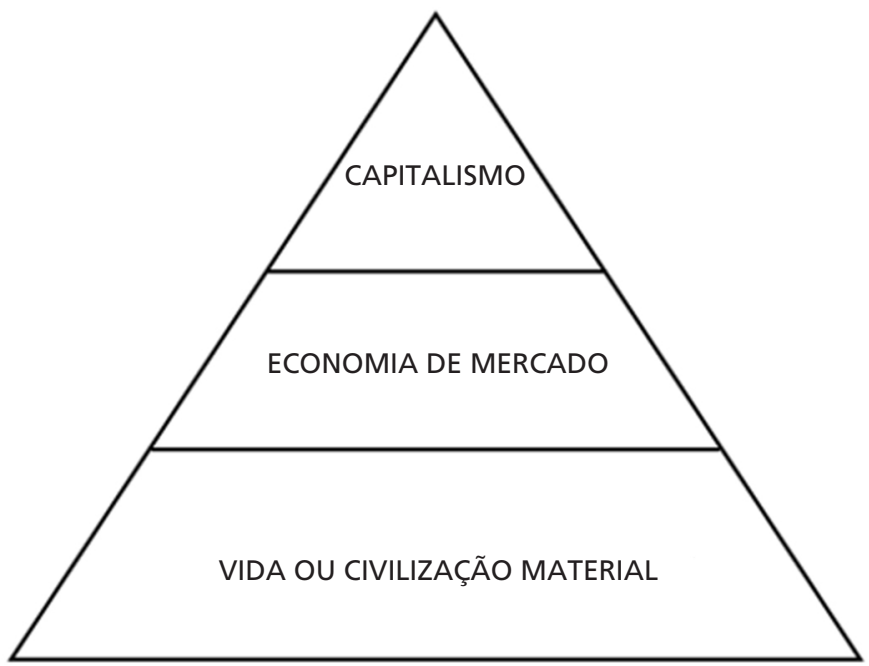

Fonte: Elaborado pelos autores. 
formação de monopólios e pelo privilégio das relações com o Estado. ${ }^{8}$ Enfim, o capitalismo é concebido como a camada superior não especializada da hierarquia do mundo do comércio. Por conseguinte, a flexibilidade, o ecletismo e a liberdade de escolha foram as características essenciais de sua unidade, desde a Itália do século XIII.

Arrighi (2003) defende que a concepção braudeliana do capitalismo pode ser tomada como uma reafirmação da fórmula geral do capital de Marx (DMD'). 0 capital-dinheiro (D) é o mesmo que liquidez, flexibilidade e liberdade de escolha. 0 capital-mercadoria (M) indica a expectativa de lucro com base no investimento numa dada combinação de insumo-produto e, dessa maneira, significa concretude, rigidez, estreitamento e fechamento das opções. Por fim, D' expressa a ampliação da liquidez, da flexibilidade e da liberdade de escolha. Assim, não são as inversões em combinações específicas de insumo-produto que tornam um agente capitalista. Tais inversões são apenas um meio contingente para alcançar seus objetivos, ou seja, "para chegar à finalidade de assegurar uma flexibilidade e liberdade de escolha ainda maiores num momento futuro" (ibid., p. 5).

Ainda de acordo com Arrighi (ibid.), quando há frustração da expectativa de aumento da liberdade de escolha, "o capital tende a retornar a formas mais flexíveis de investimento - acima de tudo, à sua forma monetária". Dito de outro modo, trata-se da questão da preferência pela liquidez. ${ }^{9} \mathrm{Ou}$ seja, sendo absolutamente flexíveis e ecléticas, as ações dos principais agentes capitalistas ora indicam o sentido geral de territorialização e de investimento em formas materiais de expansão econômica, ora desterritorializam-se e assumem formas mais líquidas de valorização dos capitais. Fazem isso sempre a partir da mediação fundamental com os poderes estatais e com o objetivo de ampliar sua liquidez, sua flexibilidade, enfim, sua liberdade de escolha. A partir dessa caracterização do capitalismo, em geral oposta à concepção de modo de produção, Braudel (1987) estabeleceu e demonstrou a ideia de que todas as fases de significativa expansão material da economia-mundo capitalista foram sucedidas por fases de expansão financeira. Portanto, em consonância com a matriz de pensamento braudeliana, defendemos que a financeirização contemporânea deve ser considerada como um dos momentos históricos recorrentes em que "os agentes capitalistas passam a 'preferir' a liquidez, e uma parcela incomumente grande de seus recursos tende a permanecer sob forma líquida" (Arrighi, 2003, p. 5). Esse é o pressuposto básico da concepção dos ciclos sistêmicos de acumulação que apresentaremos a seguir.

\section{A concepção dos ciclos sistêmicos de acumulação}

As teses e as teorias sobre o advento de um regime de acumulação financeirizado (Chesnais, 1996 e 2002) indicam que, ao menos desde a metade dos anos 1970, há uma preponderância crescente dos capitais de aplicação financeira em relação à totalidade dos capitais que circulam na economia mundial. No contexto do esgotamento do regime de acumulação fordista-keynesiano, esse processo teria coincidido com mudanças estruturais no alcance e 
no conteúdo da mundialização do capitalismo. Chesnais (1996) observa que, a partir de então, "o estilo de acumulação é dado pelas novas formas de centralização de gigantescos capitais financeiros" (p.15). Segundo Paulani (2013), consagradas na literatura de economia política nacional e internacional desde a década de 1990, as teses e as teorias sobre a financeirização do capitalismo apontam que:

[...] a partir de meados dos anos 1970, 0 capitalismo ingressa numa fase em que a valorização financeira vai adquirindo um papel cada vez mais importante, até assumir o comando do processo de acumulação. Em outras palavras, atualmente, o processo de valorização do valor que é definidor do capitalismo, estaria sob o comando da lógica financeira, que é rentista e curto-prazista, além de ainda mais contraditória do ponto de vista do funcionamento do sistema como um todo ou, se quisermos, do ponto de vista da acumulação sistêmica. (p. 255)

Para nós, os limites das teses e teorias sobre a emergência de um regime de acumulação financeirizado ou com dominância financeira dizem respeito, principalmente, à excessiva ênfase nas transformações econômicas contemporâneas. Com efeito, formulações como as de Aglietta (apud Chesnais, 2002) sugerem que, ao menos nos países centrais, sobretudo nos Estados Unidos, algo como um "capitalismo de amanhã" estaria em desenvolvimento. Como não acreditamos que a atual fase de expansão financeira constitui uma etapa inteiramente nova do capitalismo, defendemos, em consonância com a abordagem de matriz braudeliana de Arrighi (2003), que é necessário ampliar os horizontes espaço-temporais de análise da denominada financeirização.
A evidência de que algo fundamental se transformou no modo como funciona o capitalismo, nos anos 1970, também é o ponto de partida das reflexões de Arrighi (ibid.). Como o próprio autor sugere, suas indagações se assemelham às de Harvey (2007), cuja tese é bastante conhecida:

Vem ocorrendo uma mudança abissal nas práticas culturais, bem como político-econômicas, desde mais ou menos 1972.

Essa mudança abissal está vinculada à emergência de novas maneiras dominantes pelas quais experimentamos 0 tempo e o espaço. [...] Mas essas mudanças, quando confrontadas com as regras básicas de acumulação capitalista, mostram-se mais como transformações da aparência superficial do que como sinais do surgimento de alguma sociedade pós-capitalista ou mesmo pós-industrial inteiramente nova. (p. 8)

Para ambos, períodos de crise, reestruturação e reorganização são inerentes à reprodução ampliada do capitalismo. Não obstante, Arrighi (2003) busca esclarecer as tendências contemporâneas à luz de padrões de repetição e evolução de longa duração. ${ }^{10}$ Conforme 0 autor:

Nossa tese é a de que, de fato, a história do capitalismo está atravessando um momento decisivo, mas essa situação não é tão sem precedentes quanto poderia parecer à primeira vista. Longos períodos de crise, reestruturação e reorganização - ou seja, de mudanças com descontinuidade - têm sido muito mais típicos da história da economia capitalista mundial do que os breves momentos de expansão generalizada por uma via de desenvolvimento definida, como a que ocorreu nas décadas de 1950 e 1960. No passado, esses longos períodos de mudanças 
com descontinuidade terminaram em reorganizações da economia capitalista mundial sobre bases novas e mais amplas. (p. 1)

Ao desenvolver sua tese, Arrighi (ibid.) recorreu à fórmula geral do capital de Marx (DMD') para compreender, não apenas a lógica dos investimentos capitalistas individuais, mas, igualmente, o padrão reiterado do capitalismo histórico como sistema mundial. Esse padrão é definido pela alternância de fases de expansão material, nas quais os capitais são investidos em combinações específicas de insumo-produto, e de fases de renascimento e expansão financeiros, nas quais os capitais se libertam de sua forma mercadoria. Associadas, essas duas fases constituem um completo ciclo sistêmico de acumulação.

As fases de expansão material (DM) caracterizam-se por mudanças contínuas, isto é, a economia capitalista cresce por uma única via de desenvolvimento. Por sua vez, as fases de expansão financeira (MD') caracterizam-se por mudanças descontínuas, quando o crescimento pela via estabelecida atinge seu limite, impondo reestruturações sob a liderança de determinados blocos de agentes governamentais e empresariais. Ou seja, "em toda e qualquer expansão financeira, o capitalismo mundial reorganizou-se ainda mais fundamentalmente sob uma nova liderança" (Arrighi e Silver, 2001, p. 41, tradução nossa). Por conseguinte, a expansão do capitalismo vinculou-se à competição interestatal pelo capital circulante ${ }^{11} \mathrm{e}$ à emergência de estruturas políticas dotadas de capacidades organizacionais cada vez mais amplas e complexas.

Arrighi (2003) identificou quatro ciclos sistêmicos de acumulação: 1) o ciclo genovês (do século XV ao início do século XVII); 2) o ciclo holandês (do fim do século XVI até a maior parte do século XVIII); 3) o ciclo britânico (da segunda metade do século XVIII até o início do século XX); e 4) o ciclo norte-americano (do final do século XIX até o período contemporâneo). Em cada um dos ciclos, combinaram-se, de maneira contraditória, duas lógicas de poder distintas, dando forma à economia capitalista mundial e ao moderno sistema interestatal. Sobre as relações entre as lógicas territorialista e capitalista do poder, o autor propõe o seguinte:

Parafraseando a fórmula geral do capital de Marx sobre a produção capitalista (DMD'), podemos traduzir a diferença entre essas duas lógicas do poder pelas fórmulas TDT' e DTD', respectivamente. Segundo a primeira fórmula, o domínio econômico abstrato, ou o dinheiro (D), é um meio ou elo intermediário num processo voltado para a aquisição de territórios adicionais $\left(T^{\prime}-T=+\Delta T\right)$. De acordo com a segunda fórmula, o território $(\mathrm{T})$ é um meio ou um elo intermediário num processo voltado para a aquisição de meios de pagamento adicionais $\left(D^{\prime}-D=\right.$ $+\Delta D)$. (p. 33)

A combinação contraditória dessas lógicas correspondeu à formação de blocos capitalistas/territorialistas de poder, baseados em regimes de acumulação particulares e capazes de exercer funções de governo e liderança sobre um sistema de nações soberanas. Em sua análise comparativa dos ciclos genovês, holandês, britânico e norte-americano, Arrighi (ibid.) sublinha o padrão recorrente de ascensão, plena expansão e superação desses blocos de poder.

Em primeiro lugar, há um período de expansão financeira no decorrer do qual um 
novo regime de acumulação se desenvolve dentro das estruturas do antigo regime. Em seguida, há uma fase de consolidação e desenvolvimento do novo regime, no qual seus agentes fundamentais promovem e se beneficiam da expansão material da economia mundial. Por último, há outro momento de expansão financeira, quando as contradições do regime plenamente desenvolvido criam oportunidades para a ascensão de regimes concorrentes, um dos quais se torna dominante. Reunidas, essas etapas constituem "séculos longos" - progressivamente mais curtos, em virtude da aceleração dos ritmos da história capitalista (Figura 2).

0 início de cada fase de expansão financeira é marcado por uma crise sinalizadora do regime de acumulação dominante, isto é, o momento em que os principais agentes dos processos sistêmicos de acumulação revelam "uma avaliação negativa da possibilidade de continuar a lucrar com o reinvestimento do capital excedente na expansão material da economia mundial" (ibid., p. 220). Concomitantemente, estabelecem-se as condições para uma "avaliação positiva da possibilidade de prolongar sua liderança/dominação, no tempo e no espaço, através de uma especialização maior nas altas finanças" (ibid.). Além da especialização nas altas finanças, os momentos de "colheita dos frutos" de uma fase anterior de expansão material apresentam, segundo o autor, as seguintes características fundamentais: 1) intensificação da concorrência intergovernamental e intercapitalista; 2) crescimento do controle dos interesses monetários sobre os governos e 3) consumo ostensivo de produtos culturais. Encerradas as

Figura 2 - Séculos longos e ciclos sistêmicos de acumulação



Fonte: Arrighi (2003). 
oportunidades de expansão financeira, a crise sistêmica subjacente transforma-se na crise terminal do regime de acumulação dominante. Abre-se espaço para uma nova expansão material da economia mundial monitorada por um novo bloco hegemônico de agentes capitalistas e territorialistas.

Portanto, a financeirização como padrão sistêmico de riqueza do capitalismo contemporâneo - cujo advento remonta às transformações econômicas estruturais iniciadas nos anos 1970 - possui precedentes nos ciclos sistêmicos de acumulação anteriores ao norte-americano. No entanto, não se trata da simples repetição do que ocorreu nos demais ciclos. A narrativa histórico-estrutural de Arrighi (ibid.) admite como igualmente relevantes processos sistêmicos de repetição e de inovação. Isto coloca uma questão fundamental: o que há de novo na atual fase de expansão financeira do capitalismo? Em consonância com Braga (1997) e Paulani (2016), destacamos os seguintes aspectos fundamentais:

a) a escala, o alcance, o volume e a profundidade dos negócios e da lógica financeira;

b) a securitização, entendida, em sentido amplo, como "o processo pelo qual empresas produtivas, bancos, demais empresas financeiras e governos emitem títulos de dívida, com inúmeras finalidades, envolvendo e interligando, dessa forma, os mercados creditícios, de capitais, de derivativos" (Braga, 1997, p. 198);

c) a crescente substituição, nos mercados financeiros em geral, da importância relativa das moedas e dos depósitos à vista por ativos financeiros geradores de juros - isto é, ativos dotados, a um só tempo, de liquidez e de rentabilidade; d) as novas formas de organização capitalista que apontam, de um lado, para a formação de conglomerados globais de serviços financeiros e, de outro, para a ampliação das funções financeiras no interior das corporações produtivas;

e) a transformação da gestão da riqueza em gestão de portfólios de negócios. Quer dizer, todos os agentes privados relevantes tendem, cada vez mais, a organizar suas ações de modo multiescalar, multifuncional e multissetorial;

f) a fragilização da capacidade regulatória dos Estados nacionais e territoriais. Fragilização evidenciada, por exemplo: 1) no modo como se tornaram emprestadores de última instância; 2) no crescimento do componente financeiro dos déficits públicos; e 3) na diminuição relativa da influência dos gastos governamentais sobre as rendas nacionais.

g) o rentismo como traço característico dos contemporâneos processos de acumulação de capital. Acumulação que, de acordo com Paulani (2016), "se dá sob os imperativos da propriedade mais do que da produção e propriedade que é cada vez mais de capital fictício do que de meios de produção" (p. 533).

A hipótese central que orienta nossa pesquisa sugere que as características distintivas da atual fase de expansão financeira do capitalismo desencadearam um novo ciclo de mercantilização generalizada que tende a alcançar e aprofundar-se em todos os âmbitos ou dimensões da vida social. Portanto, antes de ilustrarmos de que maneira a financeirização produz impactos urbanos e territoriais típicos do período contemporâneo, é necessário definir o modo como compreendemos o fenômeno da mercantilização. 


\section{0 que é mercantilização?}

Consideramos que a definição do conceito de mercantilização exige, antes de tudo, a definição do conceito de mercadoria. Tal como Jessop (2007), optamos por uma síntese que atribui à mercadoria três sentidos básicos:

a) uma mercadoria é, em primeiro lugar, um bem ou serviço produzido para a venda por intermédio do processo de trabalho;

b) na acepção marxista, uma mercadoria capitalista é aquela produzida por intermédio do processo de trabalho submetido à concorrência capitalista. Isto é, aos imperativos de diminuição do tempo de trabalho e do tempo de rotação do capital socialmente necessários;

c) por último, uma mercadoria fictícia, nos termos de Karl Polanyi, é aquela que possui a forma de uma mercadoria - pode ser comprada e vendida -, mas que não foi necessariamente e originalmente produzida para a venda. $\mathrm{Ou}$ seja, ela já existe na "natureza" ou foi criada apenas com um valor de uso antes de adquirir um valor de troca.

Como se sabe, Polanyi (2012) descreveu o surgimento e a consolidação da economia de mercado, na Europa do século XIX, como o resultado de um duplo movimento. De um lado, "os mercados se difundiam sobre toda a face do globo", de outro, "uma rede de medidas e políticas se integravam em poderosas instituições destinadas a cercear a ação do mercado relativa ao trabalho, à terra e ao dinheiro" (p. 88). De acordo com essa perspectiva, o trabalho, a terra e o dinheiro são mercadorias fictícias, elementos da natureza e da sociedade que não foram originalmente produzidos para a venda. ${ }^{12}$ Portanto, a transformação do trabalho, da terra e do dinheiro em mercadorias e em elementos fundamentais da atividade industrial pode ser interpretada como um processo de mercantilização que resultou da denominada Revolução Industrial, na medida em que 0 advento de maquinarias e fábricas complexas exigiu seu fornecimento permanente, sistemático e por intermédio de mecanismos de mercado.

Segundo Polanyi (ibid.), o duplo movimento de mercantilização e desmercantilização do trabalho, da terra e do dinheiro fundou-se em "dois princípios organizadores da sociedade (liberal), cada um deles determinando os seus objetivos institucionais específicos, com o apoio de forças sociais definidas e utilizando diferentes métodos próprios" (ibid., p. 139). Conforme o autor:

Um foi o princípio do liberalismo econômico, que objetivava estabelecer um mercado autorregulável, dependia do apoio das classes comerciais e usava principalmente o laissez-faire e o livre comércio como seus métodos. 0 outro foi o princípio da proteção social, cuja finalidade era preservar o homem e a natureza, além da organização produtiva, e que dependia do apoio daqueles mais imediatamente afetados pela ação deletéria do mercado - básica, mas não exclusivamente, as classes trabalhadoras e fundiárias - e que utilizava uma legislação protetora, associações restritivas e outros instrumentos de intervenção como seus métodos. (Ibid.)

Dito de outro modo, se o princípio do liberalismo foi o que se identificou com o objetivo de estabelecer mercados globais autorreguláveis, o princípio da proteção social, por sua vez, correspondeu aos contramovimentos que buscavam evitar a subordinação 
total da "substância da própria sociedade às leis de mercado" (ibid., p. 77). Na origem dessa formulação, está o pressuposto que indica que as sociedades seriam completamente desarticuladas e, no limite, destruídas se a utopia liberal da sociedade de mercado fosse plenamente realizada.

Pois bem, seguindo o renovado interesse pelo pensamento de Karl Polanyi, ${ }^{13}$ Silver e Arrighi (2014) ressaltam que, como no século XIX, os movimentos contemporâneos em direção a mercados autorreguláveis, nos marcos da "globalização neoliberal", também desencadearam "um contramovimento de proteção das perturbações causadas pela intensificação da concorrência mundial por capital e mercados" (p. 23). No entanto, há diferenças no modo como o duplo movimento se realizou em cada caso - diferenças que podem ser compreendidas tomando os ciclos sistêmicos de acumulação britânico e norte-americano como referências de periodização.

No ciclo sistêmico de acumulação britânico, a Revolução Industrial e a afirmação dos princípios do liberalismo foram decisivas para a formação e expansão dos mercados globais autorregulados. Por um lado, como já mencionado, impôs-se a necessidade de mercantilização e fornecimento sistemático dos elementos fundamentais da atividade industrial. Por outro, a aceitação generalizada dos princípios clássicos do liberalismo tornou-se uma força adicional. Quer dizer, acompanhando as exigências de transformação do trabalho, da terra e do dinheiro em mercadorias, esses princípios foram resumidos da seguinte maneira: 1) o trabalho deve encontrar seu preço no mercado; 2) a criação do dinheiro precisa ser objeto de um mecanismo automático; e 3) os bens devem circular livremente entre países. ${ }^{14}$

Silver e Arrighi (ibid.) assinalam que a principal distinção entre as hegemonias e os ciclos sistêmicos de acumulação britânico e norte-americano refere-se, justamente, ao afastamento dos Estados Unidos dos princípios e práticas do liberalismo da Grã-Bretanha, tal como descritos acima. Em sua opinião, esse distanciamento pode ser explicado pelas diferenças na estrutura e organização dos sistemas globais de governo e acumulação centrados, sucessivamente, na Grã-Bretanha e nos Estados Unidos. 0 Quadro 2 sintetiza alguns critérios de comparação.

Para Arrighi (2003), os ciclos britânico e norte-americano distinguiram-se, principalmente, pelo caráter respectivamente extrovertido e autocentrado das economias da Grã-Bretanha e dos Estados Unidos. Dentre os fatores responsáveis pela natureza extrovertida da economia britânica e que permitiram sua adesão unilateral aos princípios do livre comércio, Silver e Arrighi (2014) destacam, de um lado, o papel da Grã-Bretanha como entreposto comercial e financeiro da economia global e, de outro, o império do qual extraía tributos e forças militares adicionais - sobretudo da Índia. Por sua vez, na primeira metade do século $X X$, a economia norte-americana não exercia funções de entreposto e não controlava diretamente um império territorial além de suas próprias fronteiras. Entretanto, possuía dimensões continentais e era amplamente autossuficiente.

0 caráter autocentrado e autossuficiente da economia norte-americana, isto é, a abundância de recursos demográficos e territoriais, dispensava a necessidade de abertura 


\section{Quadro 2 - Comparação da relação hegemônica dos Estados com a economia política global}

\begin{tabular}{|l|l|l|}
\hline \multirow{2}{*}{} & \multicolumn{2}{|c|}{ Sistema mundial de governo e acumulação } \\
\cline { 2 - 3 } & \multicolumn{1}{|c|}{ Centrado no Reino Unido } & \multicolumn{1}{c|}{ Centrado nos Estados Unidos } \\
\hline Relação estrutural predominante & Entreposto/complementar & Autocentrado/competitivo \\
\hline Principal instrumento de reorganização & Comércio livre unilateral/tributo colonial & $\begin{array}{l}\text { Liberalização comercial negociada/ } \\
\text { investimento direto estrangeiro }\end{array}$ \\
\hline $\begin{array}{l}\text { Principal restrição na capacidade } \\
\text { de reorganização }\end{array}$ & $\begin{array}{l}\text { Equilibrio do poder/rivalidades } \\
\text { interimperialistas }\end{array}$ & $\begin{array}{l}\text { Poder social dos grupos subordinados/ } \\
\text { desafios comunistas e nacionalistas }\end{array}$ \\
\hline
\end{tabular}

Fonte: Silver e Arrighi (2014).

unilateral de seu mercado interno para as exportações de todo o mundo. Concomitantemente, ensejou meios diversos de reorganização da economia global em torno da potência hegemônica. No pós-Segunda Guerra Mundial, o desequilíbrio entre a renda nacional e o poder militar dos Estados Unidos e o dos demais países tornaram-se prerrogativas na definição dos termos dos acordos bilaterais e multilaterais de comércio. ${ }^{15}$ Mais precisamente, tornaram-se vantagens consideráveis "na indução de outros Estados no sentido de que entrassem em negociações para a liberalização do comércio e cedessem à pressão dos EUA no decurso das negociações" (ibid., p. 17).

Do mesmo modo, as novas condições hegemônicas fundamentaram-se na internalização dos custos de transação. Quer dizer, a internalização, no campo organizacional de corporações verticalmente integradas, de atividades antes executadas por unidades empresariais distintas. 0 surgimento e expansão das modernas corporações transnacionais permitiram aos Estados Unidos conquistar mercados por intermédio de investimentos externos diretos, mesmo quando esses mercados estivessem protegidos contra importações estrangeiras.

No que se refere aos contramovimentos de proteção social, a primeira distinção remete ao papel das forças sociais subordinadas. Conforme Silver e Arrighi (ibid.), no ciclo sistêmico de acumulação norte-americano, essas forças restringiram, desde 0 início, 0 movimento no sentido da autorregulação. $\mathrm{Ou}$ seja, a partir da segunda metade do século $\mathrm{XX}$, os contramovimentos teriam antecipado 0 movimento em direção a mercados autorreguláveis. De acordo com essa interpretação, no ciclo norte-americano, o poder social dos grupos subordinados e os desafios "comunistas" e "nacionalistas" tornaram-se os principais fatores de limitação da capacidade dos Estados Unidos de reorganizar o sistema mundial e de promover o livre comércio. 
A segunda diferença fundamental diz respeito à ausência da principal força desestabilizadora dos mercados globais autorregulados centrados na Grã-Bretanha. Silver e Arrighi (ibid.) indicam que, no ciclo norte-americano, principalmente na fase de expansão financeira, a autocracia das potências capitalistas foi substituída pela centralização do poder militar nos Estados Unidos e por uma crescente interdependência das unidades territoriais que compõem o moderno sistema interestatal. ${ }^{16}$

Observadas as características distintivas do duplo movimento nos ciclos sistêmicos de acumulação britânico e norte-americano, Silver e Arrighi (ibid.) defendem que, ao lado da "resistência vinda do Sul do mundo" (p. 24), uma das fontes mais importantes de reversão do impulso à formação contemporânea de mercados globais autorregulados é o próprio protecionismo dos Estados Unidos. Segundo os autores:

Uma fonte mais provável de reversão do processo de formação do mercado mundial centrado nos EUA é o seu próprio protecionismo persistente. Como já observado, mesmo no auge de sua cruzada para mercados abertos e livres, os Estados Unidos têm pregado, muito mais do que praticado, o credo liberal. [...] Esta é outra diferença importante entre 0 funcionamento do duplo movimento de Polanyi sob o domínio britânico e sob a hegemonia dos EUA. Embora a Grã-Bretanha consistentemente tenha aderido ao movimento de comércio livre, os Estados Unidos têm sido muito menos consistentes, minando assim a credibilidade da sua cruzada para mercados abertos e livres. [...] As inconsistências dos EUA são sem dúvida um grande fator contribuinte para o contramovimento para a proteção da sociedade. (lbid.)
Ou seja, os contramovimentos de proteção social não são necessariamente anticapitalistas e/ou contra-hegemônicos. ${ }^{17}$ São, antes de tudo, formas de estabilização que permitem a continuidade dos processos de acumulação de poder e capital. Para explicar esses processos gerais de estabilização, defendemos, em consonância com Fiori (2000), uma releitura da teoria do duplo movimento que o decomponha em quatro movimentos. Ao fazê-lo, há que se considerar as duas contradições essenciais do capitalismo: "a contradição entre capital e trabalho e a contradição entre a globalidade dos seus fluxos econômicos e a territorialidade de sua gestão política" (ibid., p. 70). Em outras palavras, existe uma face do duplo movimento que corresponde aos conflitos entre capital e trabalho - principalmente, mas não exclusivamente, no interior de cada Estado-economia nacional - e outra que se refere à competição interestatal. ${ }^{18}$ Ambas, variando no tempo e no espaço da economia-mundo, foram responsáveis por determinar a existência de formas institucionais e de coesão social funcionais ao desenvolvimento do capitalismo, mesmo que, para tanto, tenham limitado a expansão das forças de mercado. ${ }^{19}$

Em suma, o duplo movimento e suas especificidades espaço-temporais referem-se às tensões entre os objetivos de mercantilização e de desmercantilização dos principais elementos da vida material e coletiva. Em consonância com a matriz braudeliana que orienta nossas reflexões, destacamos, dentre esses elementos, além do trabalho, da terra e do dinheiro, o papel fundamental das cidades. ${ }^{20}$ Assim, para ilustrar nosso ponto de vista e concluir o presente artigo, esboçaremos, a seguir, algumas 
indicações do modo como os processos gerais de mercantilização, desencadeados pela atual fase de expansão financeira do capitalismo, possuem dimensões urbano-territoriais.

\section{Conclusão: impactos urbanos e territoriais da financeirização- -mercantilização contemporâneas}

Em nossa opinião, até aproximadamente o final dos anos 1960, sobretudo nos países centrais e nos marcos do regime de acumulação fordista-keynesiano, o duplo movimento assinalado por Polanyi (2012) correspondeu a uma tendência de desmercantilização parcial das cidades. Tal como Topalov (1991), podemos dizer, para fins de ilustração, que o advento e a difusão do urbanismo e do planejamento urbano e regional, abrangentes e regulatórios, coincidiram com a emergência de um ideário reformador incompatível com os interesses imediatos de mercado. 0 que não quer dizer que esse ideário tenha sido completamente disfuncional em relação ao desenvolvimento capitalista. Muito ao contrário, foi um componente fundamental da estabilização e do crescimento econômico no contexto do capitalismo do pós-Segunda Guerra Mundial. No que se refere, por exemplo, à habitação de interesse social, Rolnik (2015) aponta que, particularmente nas décadas de 1950 e 1960, "a provisão pública de habitação constituiu-se em um dos pilares da construção de uma política de bem-estar social na Europa, um pacto redistributivo entre capital e trabalho que sustentou décadas de crescimento" (p. 35).
Por sua vez, na atual fase de expansão financeira do capitalismo, as múltiplas formas de mercantilização das cidades correspondem a uma inversão do movimento anterior. Segundo essa perspectiva, a crise sinalizadora do ciclo sistêmico de acumulação norte-americano, a crise do regime de acumulação fordista-keynesiano e a ascensão do neoliberalismo, a partir do final da década de 1960, deram lugar a uma reestruturação espaço-temporal fundada, entre outros fatores, na busca por alternativas mais rentáveis de aplicação de capitais excedentes - capitais sobreacumulados que não podiam ser reinvestidos de maneira lucrativa nos setores tradicionais da produção material. Dentre essas formas, sobressaiu, sem dúvida, o investimento de capitais financeiros nos mercados imobiliários e no desenvolvimento urbano em geral. Ainda no que diz respeito ao exemplo da habitação, Rolnik (ibid.) considera que esse processo levou à sua desconstrução como bem social e à sua "transmutação em mercadoria e ativo financeiro" (p. 26).

Ou seja, o papel das cidades, como elementos centrais da vida material e como bases da reprodução geral da ordem capitalista, mudou ao longo do tempo. De parcialmente desmercantilizadas, as cidades passaram a ser tratadas como mercadorias e entraram nos circuitos da valorização financeirizada. Conforme Paulani (2016), defendemos que a contemporânea fase de expansão financeira do capitalismo ampliou a tendência geral de transformação do espaço urbano em um campo aberto para a circulação de capitais portadores de juros, 0 que permite uma aliança entre proprietários de terra e capitalistas e só é possível à medida que são deslocadas as demais formas de propriedade. De acordo com a autora: 
[...] para que desapareça a contradição entre a lei do valor e a existência da renda fundiária, a terra deve se constituir num campo aberto à circulação do capital portador de juros, ou seja, deve ser tratada como capital fictício. Isso significa que o preço da terra deve refletir a permanente busca do capital por rendas futuras aumentadas. Esse arranjo permite a coordenação do processo de utilização da terra, de modo a se garantir sempre os melhores e mais lucrativos usos e a maximizar a produção de valor excedente. A situação ideal é que toda terra seja assim encarada, de modo que todas as outras formas de propriedade da terra desapareçam. [...] 0 importante a destacar é 0 caráter virtuoso da associação entre captura de renda e busca de lucro que a circulação do capital portador de juros pode propiciar. (Ibid., p. 528)

Quer dizer, a terra urbana torna-se, a um só tempo, capital fictício e mercadoria fictícia. A cidade tende a ser, cada vez mais, não apenas um negócio, mas um negócio líquido e rentável. Para nós, o exemplo da mercantilização das cidades reforça interpretações como as de Bienefeld (2007), que, ao contrário de Silver e Arrighi (2014), sugere a possibilidade, não da antecipação, mas do retardamento, da distorção ou mesmo da supressão dos contramovimentos de proteção social diante da contemporânea "ditadura das finanças" e da "revolução neoliberal". 21

Pois bem, do nosso ponto de vista, é possível considerar os impactos urbanos e territoriais da financeirização-mercantilização contemporâneas destacando ao menos três aspectos básicos.

Em primeiro lugar, ressaltamos o surgimento de distintas formas de empreendedorismo urbano e territorial. Em nossa perspectiva, essas novas formas de empreendedorismo correspondem à fragilização das capacidades regulatórias dos Estados nacionais e territoriais. Recorrendo à concepção do duplo movimento, defendemos que, ao menos desde a passagem dos anos 1960 aos 1970, no centro da economia-mundo capitalista, há um relativo enfraquecimento dos mecanismos de proteção social dos Estados nacionais diante da crescente globalização, financeirização e liberalização dos fluxos econômicos. Por sua vez, na periferia e na semiperiferia, o Estado-nação não existe em sua forma plena. Assim, a permanente excentricidade dos Estados territoriais periféricos e semiperiféricos, em relação à dinâmica do núcleo central da economia-mundo e de seu sistema de gestão interestatal, torna ainda menores as possibilidades de reação em face das forças nacionais e internacionais mercantilizadoras. Nesse contexto, os Estados em geral, em seus distintos níveis de governo, assumem, crescentemente, o papel de promotores de políticas de criação de espaços competitivos, abandonando a concepção do planejamento abrangente e regulador do mercado.

As iniciativas de empreendedorismo urbano e territorial traduzem-se, por exemplo, nas denominadas Parcerias Público-Privadas (PPPs). É o caso de projetos como o Porto Maravilha, uma política de "revitalização" de uma área de 5 milhões de $\mathrm{km}^{2}$ nas proximidades da área central do Rio de Janeiro. A lei municipal que instituiu o Porto Maravilha flexibilizou parâmetros de uso e ocupação do solo, estabeleceu intervenções prioritárias de infraestrutura e transporte, assim como mecanismos público-privados de gestão e financiamento. Um consórcio de empresas privadas - o Consórcio Porto Novo (OAS, 
Odebrecht e Carioca Engenharia) - foi contratado para realizar obras e serviços urbanos, por um prazo de 15 anos, no valor estimado inicial de $\mathbf{R} \$ 7,6$ bilhões. Esse valor resultaria da comercialização de Certificados de Potencial Adicional de Construção (Cepacs), que são emitidos pelas autoridades municipais e podem ser adquiridos por investidores privados. A venda dos títulos - que podem, inclusive, ser negociados em bolsas de valores - financiaria as obras. No entanto, um Fundo de Investimento Imobiliário (FII) organizado por um banco público, a Caixa Econômica Federal (CEF), adquiriu a totalidade dos títulos, liberando os recursos para o início de obras e serviços. Até o presente momento, apenas $8,74 \%$ deles foram recomprados por investidores privados. ${ }^{22}$ Quer dizer, apesar dos discursos sobre a origem privada dos investimentos, na prática, o Estado assumiu os riscos. ${ }^{23}$

Algo semelhante sucedeu com parte das políticas urbanas setoriais, principalmente de habitação, cada vez mais próximas das lógicas do mercado imobiliário e das inovações financeiras. No Brasil, por exemplo, o lançamento do Programa Minha Casa Minha Vida, em 2009, reproduziu um padrão histórico de apropriação de fundos públicos por agentes privados. Para Rolnik (2015):

0 programa é representativo de padrões específicos de articulação entre agentes públicos e privados no capitalismo brasileiro. Se, por um lado, foi desenhado para incentivar empresas privadas a se comprometerem com a produção de habitação para moradores de baixa renda, por outro, permaneceu altamente dependente de recursos públicos, mobilizados para subsidiar a aquisição da propriedade por compradores de baixa e média rendas.
Esse arranjo financeiro ambivalente implica a transferência de riscos para as instituições públicas, ao mesmo tempo que mantém os lucros - geralmente aumentados por subsídios indiretos - com agentes privados. $^{24}$ (p. 309)

Além disso, assinalamos a mudança radical nas estratégias e características dos agentes capitalistas que operam no âmbito dos mercados imobiliários e do desenvolvimento urbano em geral. Tal como estabelecido por parte da literatura do campo dos estudos urbanos e territoriais, há, no período contemporâneo, uma tendência crescente de inversões em ativos imobiliários, titularizados e securitizados, como uma das alternativas centrais ao problema da sobreacumulação de capitais. Em consonância com De Mattos (2016), acreditamos que a maior incidência de investimentos financeiros nas transformações urbanas modificou substancialmente a organização, o funcionamento, a morfologia e a aparência das principais cidades em todo o mundo. Do mesmo modo, implicou a mudança das estratégias e das características dos agentes mais relevantes da produção social do espaço.

Sanfelici (2013), por exemplo, destaca como o processo de abertura de capitais das principais incorporadoras/construtoras brasileiras, na primeira década do século XXI, alterou alguns aspectos fundamentais dos negócios imobiliários no Brasil. Por mais que essa abertura não indique, por si só, a completa financeirização dos mercados imobiliários brasileiros, ela estreitou os vínculos das incorporadoras/ construtoras com os mercados de capitais e induziu um processo de dispersão territorial e de ampliação da escala de investimento dessas empresas - que deixaram de operar apenas nos 
seus mercados regionais de origem, passando a atuar em escala nacional. Fizeram-no não só pela via da capitalização em bolsa de valores, mas, sobretudo, acompanhando o ciclo de expansão da produção habitacional promovido pelo Estado brasileiro e consubstanciado no Programa Minha Casa Minha Vida. ${ }^{25}$

Mudando a escala de ilustração, podemos citar, de maneira quase anedótica, a projeção de construção das Trump Towers no âmbito do mencionado Porto Maravilha. De acordo com o sítio oficial das Trump Towers Rio, a "marca Trump [...] já abrange projetos nos Estados Unidos, Panamá, Canadá e Turquia [e] é conhecida por representar o mais alto nível de excelência e luxo em propriedades residências e comerciais, hotéis, escritórios e campos de golfe". ${ }^{26}$ Na verdade, uma reportagem da BBC Brasil, de julho de 2016, intitulada "Por que o maior empreendimento de Trump no Brasil encalhou?", 27 indica que ele será eventualmente conduzido por um consórcio de seis construtoras e imobiliárias licenciadas pela marca Trump - entre as quais se destacam a búlgara MRP, a espanhola Salamanca e a brasileira Even. Ou seja, as Trump Towers Rio são apenas mais um elemento do portfólio de negócios da marca Trump. Enfim, após as eleições presidenciais nos Estados Unidos, não é preciso dizer muito sobre o nome Trump. Cumpre apenas sublinhar que, cada vez mais, os agentes capitalistas que operam nos mercados imobiliários o fazem segundo estratégias rentistas de caráter multiescalar, multifuncional e multissetorial típicas da atual fase de expansão financeira do capitalismo.

Por último, sugerimos que a profundidade da atual fase de expansão financeira do capitalismo deve ser relacionada ao grau de penetração da lógica mercantil no tecido social e urbano. Para ilustrar esse argumento, é possível tomar como referência, por exemplo, o modo como as rendas, os ativos, os patrimônios e as dívidas familiares sustentam novas formas de acumulação.

Como se sabe, diversos autores que analisaram a crise das hipotecas subprime revelaram informações sobre o desenvolvimento de uma economia de ativos vinculada aos patrimônios familiares. ${ }^{28}$ Segundo Harvey (2011), 0 ambiente macroeconômico caracterizado por juros baixos, inflação de ativos, repressão salarial e afrouxamento das restrições ao crédito transformou o refinanciamento das hipotecas numa das principais fontes de expansão do consumo das classes médias e trabalhadoras norte-americanas. Roubini e Stephen (2010), por sua vez, afirmam que os imóveis hipotecados nos Estados Unidos se tornaram uma espécie de "caixa eletrônico", ao serem mobilizados como garantias de uma cadeia permanentemente renovada de empréstimos ao consumo. Para Rolnik (2015), trata-se de novas maneiras de assegurar condições monetárias de reprodução social em face da diminuição da participação dos salários na composição da riqueza global e da pressão sobre os indivíduos e as famílias para buscarem mecanismos privados de proteção social. ${ }^{29}$

Bauman (2010) observa que a emergência de novas formas de financiamento ao consumo acompanhou a passagem de uma sociedade de produtores, na qual os lucros provinham da exploração do trabalho, para uma sociedade de consumidores, na qual os lucros se fundamentam na exploração dos desejos de consumo. Sustenta, ademais, que os indivíduos que se abstêm de tomar empréstimos e os que 
pagam seus compromissos financeiros nos prazos estabelecidos não possuem utilidade alguma para as instituições de crédito. Ou seja, "o devedor ideal é aquele que jamais paga integralmente suas dívidas" (ibid., p. 30). Em consonância com a lógica da transformação do endividamento numa fonte constante de lucros, bancos e empresas de cartão de crédito, por exemplo, "contam mais com o 'serviço' continuado das dívidas do que com seu pronto pagamento" (ibid.).

Não é preciso aceitar a tese do advento da sociedade dos consumidores para concluir que, de fato, o endividamento crescente vinculado à reprodução geral das classes trabaIhadoras e médias tornou-se uma fonte permanente de lucros financeiros. Nos termos de Sanfelici (2013), esse processo corresponde à emergência de um novo ethos financeiro fundado no "entrelaçamento inaudito das cadeias de crédito nos interstícios mais recônditos da vida social" ${ }^{30}$ (p. 30). Ainda de acordo o autor, esse entrelaçamento demonstra o modo como "o crédito e as finanças medeiam a relação entre os indivíduos, impõem ritmos no uso do tempo e engendram um ethos que define as expectativas e modela as disposições subjetivas dos indivíduos" (ibid.).
Do nosso ponto de vista, de inspiração braudeliana, estamos diante da penetração cada vez mais profunda das lógicas financeira e mercantil na camada da vida material, isto é, na camada da reprodução social. ${ }^{31} \mathrm{Em}$ consonância com Sandel (2015), acreditamos que a mudança mais decisiva do período contemporâneo foi "a extensão dos mercados, e dos valores de mercado, a esferas da vida com as quais nada têm a ver" (p. 12). Tal como formulado por Bourdieu (2002), mesmo quando integra o circuito mercantil, a casa, por exemplo, não é jamais um simples bem econômico. A casa manifesta uma forte relação de pertencimento, é um projeto ou uma aposta coletiva sobre 0 futuro da unidade doméstica e base da coesão afetiva. Ou seja, uma vez que a denominada financeirização deixou de se expressar apenas nas esferas das "altas finanças" para atingir as esferas da vida cotidiana, necessariamente emergiram graves tendências de desarticulação social. Dadas as consequências da atual crise sistêmica do capitalismo, pode-se dizer, para concluir este artigo, que essas tendências se revelam ainda mais preocupantes diante da já mencionada hipótese do retardamento, da distorção ou da supressão dos contramovimentos de proteção social.

\section{Luiz César de Queiroz Ribeiro}

Universidade Federal do Rio de Janeiro, Instituto de Pesquisa e Planejamento Urbano e Regional. Institutos Nacionais de Ciência e Tecnologia/Observatório das Metrópoles. Rio de Janeiro, RJ/Brasil. Icqribeiro@gmail.com

\section{Nelson Diniz}

Universidade Federal do Rio de Janeiro, Instituto de Pesquisa e Planejamento Urbano e Regional. Rio de Janeiro, RJ/Brasil

nelsondiniz@hotmail.com 


\section{Notas}

(1) Este artigo é uma versão amplamente modificada de trabalho anterior, preparado para a participação dos autores no XIV Seminario Internacional da Red Iberoamericana de Investigadores sobre Globalización y Territorio (RII), realizado em Monterrey, México, de 3 a 7 de outubro de 2016.

(2) Referimo-nos, mais precisamente, às consequências da denominada crise das hipotecas subprime, nos Estados Unidos. Para um relato dos efeitos dessa crise nas cidades norte-americanas, em especial no que diz respeito ao número de despejos e execuções hipotecárias, cf. Harvey (2011). Em sua obra mais recente, informada por sua atividade como relatora especial para o Direito à Moradia Adequada do Conselho de Direitos Humanos da ONU, Rolnik (2015) oferece uma ampla descrição das consequências sociais da "financeirização global da moradia".

(3) "O mérito de Braudel é, pelo seu olhar aguçado, ter detectado certas constâncias que estavam esquecidas na leitura hegemônica sobre a economia pré-industrial e que iluminam também a compreensão do mundo hoje" (Cecilio, 2012, p. 47).

(4) "[...] há ainda um outro mérito nessa abordagem descritiva de Braudel: ela se apresenta como um contraponto essencial - e radical - ao rumo que a teoria econômica adotou no último século. Como explica Morineau, a economia nesse período se desenvolveu com base em intuições geniais, porém de aplicação limitada ao mundo concreto. Assim, privilegia a análise estática, a elegância formal e a matemática. Procura se comportar como uma ciência dura, onde se pode encontrar leis universais e válidas para todos os tempos" (Cecilio, 2012, p. 47).

(5) "Por economia mundial, entende-se a economia do mundo considerada em seu todo, o 'mercado de todo o universo', como já dizia Sismondi. Por economia-mundo, palavra que forjei a partir do vocábulo alemão Weltwirtschaft, entendo a economia de somente uma porção do nosso planeta, na medida em que essa porção forma um todo econômico" (Braudel, 1987, p. 30).

(6) Segundo Braudel (1987), a Rússia, até 1869, o Império Turco, o Império Chinês, o Japão, a Índia-Insulíndia e o mundo islâmico, até o final do século XVIII, são exemplos de economias-mundos "coexistentes, que só têm entre elas trocas extremamente limitadas" (p. 31). Ao lado delas, muito antes de 1942, a Europa e o Mediterrâneo formavam, igualmente, uma totalidade econômica centrada em Veneza, Milão, Gênova e Florença.

(7) Rojas (2013) afirma que o conceito de vida ou civilização material - "que se conforma com todas aquelas realidades, elementares e cotidianas, frutos das diferentes estratégias de resposta humana às diversas pressões e coações da base geo-histórica" (p. 94) - foi desenvolvido por Braudel com o objetivo de abordar temáticas tais como as "da alimentação, dos mecanismos de reprodução demográfica e do controle do crescimento da população, da técnica, das formas do habitat, do vestuário ou dos diferentes esquemas de organização e colonização do território, tanto urbano quanto rural. São temáticas tipicamente 'antropológicas', resgatadas no conceito braudeliano da vida material, mas agora com uma clara vocação para estabelecer sua real historicidade e sua vinculação global com as demais dimensões civilizatórias da evolução humana no tempo" (p. 91).

(8) "O capitalismo só triunfa quando se identifica com o Estado, quando ele é o Estado" (Braudel, 1987, p. 25). 
(9) Para Keynes, o "desejo de manter o dinheiro como reserva de valor constitui um barômetro do grau de nossa desconfiança e de nossos cálculos e convenções quanto ao futuro" (Keynes, 1937, p. 173 apud Belluzzo, 2015, p. 30).

(10) “As indagações que geraram esse estudo são semelhantes às de Harvey. Mas as respostas são de uma investigação das tendências atuais à luz de padrões de repetição e de evolução que abarcam todo o curso do capitalismo histórico como sistema mundial. Uma vez que ampliemos, dessa maneira, o horizonte espaço-temporal de nossas observações e conjecturas teóricas, tendências que pareciam inéditas e imprevisíveis começam a afigurar-se familiares" (Arrighi, 2003, p. 4).

(11) Sobre o papel da competição interestatal pelo capital circulante na formação do capitalismo, Weber observa que: "Essa luta competitiva criou as mais amplas oportunidades para o moderno capitalismo ocidental. Os estados, separadamente, tiveram que competir pelo capital circulante, que Ihes ditou as condições mediante as quais poderia auxiliá-los a ter poder. (...) Portanto, foi o Estado nacional bem delimitado que proporcionou ao capitalismo sua oportunidade de desenvolvimento - e, enquanto o Estado nacional não ceder lugar a um império mundial, o capitalismo também persistirá" (apud Arrighi, 2003, p. 12).

(12) "Trabalho é apenas um outro nome para a atividade humana que acompanha a própria vida que, por sua vez, não é produzida para venda, mas por razões inteiramente diversas, e essa atividade não pode ser destacada do resto da vida, não pode ser armazenada ou mobilizada. Terra é apenas outro nome para a natureza, que não é produzida pelo homem. Finalmente, o dinheiro é apenas um símbolo do poder de compra e, como regra, ele não é produzido, mas adquire vida através do mecanismo dos bancos e das finanças estatais. Nenhum deles é produzido para a venda. A descrição do trabalho, da terra e do dinheiro como mercadorias é inteiramente fictícia (Polanyi, 2012, p. 78). Em nossa opinião, isso significa dizer, recorrendo à matriz braudeliana, que o trabalho, a terra e o dinheiro são elementos fundamentais da vida material.

(13) Cf., por exemplo, Bugra e Agartan (2007).

(14) Segundo Polanyi (2012), o resultado da "cruzada liberal" das décadas de 1830 e 1840 pode ser demonstrado levando em consideração a aprovação de três medidas principais pelo Parlamento britânico: 1) o Poor Law Amendment Act, de 1834, responsável por subordinar a oferta de trabalho aos mecanismos de mercado; 2) o Peel's Bank Act, de 1844, que vinculou a circulação monetária interna ao funcionamento internacional do padrão-ouro; e 3) o Anti-Corn Law Bill, de 1846, que garantiu a abertura do mercado britânico aos grãos do mundo inteiro.

(15) “Em 1948, a renda nacional dos EUA foi mais do dobro da renda nacional conjunta da Grã-Bretanha, França, Alemanha, Itália e países do Benelux e seis vezes maior do que a da URSS. [...] Finalmente, ao promover a liberalização e a expansão do comércio mundial, os Estados Unidos podiam contar com sua incontestável primazia militar vis-à-vis seus aliados no confronto com a URSS" (Silver e Arrighi, 2014, p. 17).

(16) “Não estamos dizendo que não haja brigas entre as potências capitalistas sobre o ritmo e a direção do processo de formação do mercado mundial. Simplesmente não vemos essas discussões se transformando na força motriz na reversão desse processo, como o que ocorreu no final do século XIX e no início do século XX" (Silver e Arrighi, 2014, p. 23).

(17) Segundo Bienefeld (2007), Polanyi não descartou, inclusive, a possibilidade de que os contramovimentos à expansão de mercados autorreguláveis assumissem formas fascistas. 
(18) De nossa perspectiva, a referência às contradições essenciais do capitalismo torna-se tanto mais relevante quando consideramos que, "embora Polanyi reconhecesse a existência (e, às vezes, até mesmo a importância) do poder diferencial entre classes e Estados, ele, no entanto, minimizou o papel que essas relações de poder desiguais desempenharam na determinação da trajetória histórica que ele analisava" (Silver e Arrighi, 2014, p. 7).

(19) Aqui cabe, portanto, uma vez mais, enfatizar a distinção braudeliana entre capitalismo e economia de mercado.

(20) Ao justificar por que optou pela reflexão sobre a moeda e as cidades nos últimos capítulos do primeiro volume de sua obra Civilização Material, Economia e Capitalismo - volume dedicado à camada da vida material - Braudel (1987) observa que: “Quis livrar desses temas o volume seguinte, é verdade. Mas essa razão, evidentemente, não é por si só suficiente. A verdade é que as moedas e as cidades mergulham, ao mesmo tempo, no cotidiano imemorável e na modernidade mais recente. A moeda é uma invenção muito velha, se entendo por moeda todo o meio que acelera a troca. E sem troca não há sociedade. Quanto às cidades, elas existem desde a pré-história. São as estruturas multisseculares da vida mais comum. Mas são também os multiplicadores, capazes de se adaptar à mudança, de a ajudar poderosamente. Poder-se-ia dizer que as cidades e a moeda fabricaram a modernidade; mas também, segundo a regra de reciprocidade cara a Georges Gurvitch, que a modernidade, a massa em movimento da vida dos homens, impeliu para diante a expansão da moeda, construiu a tirania crescente das cidades. Cidades e moedas são, ao mesmo tempo, motores e indicadores; elas provocam e assinalam a mudança" (p. 10).

(21) A tese central de Bienefeld (2007) é anunciada imediatamente no título original de seu trabalho sobre essa questão: Supressing the double movement to secure the dictatorship of finance.

(22) Informações do sítio oficial do Porto Maravilha na internet. Disponível em: http://www. portomaravilha.com.br/estoque. Acesso em: 10 nov 2016.

(23) Para uma descrição das características gerais do projeto Porto Maravilha, assim como de seus antecedentes, cf. Diniz (2014).

(24) Destacamos que a concepção braudeliana das relações de dependência entre capitalismo e Estado, apresentada na seção 3.3, é fundamental para a compreensão de processos econômicos típicos de formações sociais como a brasileira. Ao mesmo tempo, permite questionar até que ponto a "articulação entre agentes públicos e privados no capitalismo" é representativa da especificidade dessas formações ou pode ser entendida como uma característica estrutural do moderno sistema interestatal.

(25) Basta considerar, conforme Sanfelici (2013), que "o volume de unidades habitacionais financiadas no Brasil saltou de uma média de 250 mil por ano, entre 2000 e 2005, para mais de 1 milhão em 2010" (p. 35).

(26) Disponível em: http://www.trumptowersrio.com/pt-br/. Acesso em: 10 nov 2016.

(27) Disponível em: http://www.bbc.com/portuguese/brasil-36901182. Acesso em: 10 nov 2016.

(28) Cf., por exemplo, Lapavitsas (2009), Roubini e Stephen (2010), Harvey (2011), Fix (2011), Sanfelici (2013) e Rolnik (2015).

(29) “O uso da casa própria como estoque de riqueza, sua valorização ao longo do tempo e possibilidade de monetização funcionaram na prática como substituto potencial dos sistemas públicos de pensão e aposentadoria" (Rolnik, 2015, p. 38). 
(30) Para nós, numa ampliação da proposição de Jameson (2001), trata-se do surgimento e da generalização de algo como uma "cultura urbana do dinheiro".

(31) Braudel definiu a vida material como "a camada da não economia, o solo em que o capitalismo crava suas raízes, mas no qual nunca consegue penetrar" (apud Arrighi, 2003, p. 10). Numa atualização de seu argumento, defendemos que uma das principais especificidades da atual fase de expansão financeira diz respeito, exatamente, à penetração do capitalismo na camada da vida material.

\section{Referências}

AGLIETTA, M. (1998). Le capitalism de demain. Paris, Fondation Saint Simon.

ARRIGHI, G. (2003). O longo século XX: dinheiro, poder e as origens de nosso tempo. Rio de Janeiro, Contraponto; São Paulo, Editora Unesp.

ARRIGHI, G. e SILVER, B. J. (2001). Caos y orden en el sistema-mundo moderno. Madri, Akal.

BAUMAN, Z. (2010). Vida a crédito. Rio de Janeiro, Zahar.

BELLUZZO, L. G. (2015). O tempo de Keynes nos tempos do capitalismo. Brazilian Keynesian Review, v. 1, n. 1.

BIENEFELD, M. (2007). "Suppressing the double movement to secure the dictatorship of finance". In: BUGRA, A. e AGARTAN, K. Reading Karl Polanyi for the Twenty-First Century. Nova York, Palgrave Macmillan.

BOURDIEU. P. (2002). Las estructuras sociales de la economia. Buenos Aires, Manantial.

BOYER, R. (2000). Is a finance-led growth régime a viable alternative to fordism? Economy and Society, V. 29, n. 1 .

BRAGA, J. C. de S. (1997). "Financeirização global - O padrão sistêmico de riqueza do capitalismo contemporâneo". In: TAVARES, M. da C. e FIORI, J. L. Poder e dinheiro: uma economia política da globalização. Petrópolis, Vozes.

BRAUDEL, F. (1987). A dinâmica do capitalismo. Rio de Janeiro, Rocco.

(1990). História e ciências sociais. Lisboa, Editorial Presença.

BUGRA, A. e AGARTAN, K. (2007). Reading Karl Polanyi for the Twenty-First Century: market economy as a political project. Nova York, Palgrave Macmillan.

BUKHARIN, N. (1986). A economia mundial e o imperialismo. São Paulo, Nova Cultural.

CECILIO, M. B. (2012). Fernand Braudel no mundo contemporâneo e a acumulação acelerada de riquezas: economia de mercado e capitalismo como opostos? Dissertação de Mestrado. Rio de Janeiro, Universidade Federal do Rio de Janeiro. 
CHESNAIS, F. (1996). A mundialização do capital. São Paulo, Xamã.

(2002). A teoria do regime de acumulação financeirizado: conteúdo, alcance e interrogações. Economia e Sociedade. Campinas, v. 11, n. 1 (18), pp. 1-44.

DE MATTOS, C. A. (2016). Financiarización, mercantilización y metamorfosis planetaria: lo urbano en la valorización del capital. Sociologias. Porto Alegre, v. 18, n. 42, pp. 24-52.

DINIZ, N. (2014). Porto Maravilha: antecedentes e perspectivas da revitalização da região portuária do Rio de Janeiro. Rio de Janeiro, Letra Capital.

FIORI, J. L. (2000). A propósito de uma construção interrompida. Economia e Sociedade. Campinas, v. 9, n. 1, pp. 1-19.

(2014). História, estratégia e desenvolvimento: para uma geopolítica do capitalismo. São Paulo, Boitempo.

FIX, M. (2011). Financeirização e transformações recentes no circuito imobiliário no Brasil. Tese de Doutorado. Campinas, Universidade Estadual de Campinas.

GARCÍA-LAMARCA, M. e KAIKA, M. (2016). Mortgaged lives: the biopolitics of debt andhousing financialisation. Manchester, Transactions Institute of British Geographers.

HARVEY, D. (2007). A brief history of neoliberalism. Oxford, Oxford University Press. (2011). O enigma do capital: e as crises do capitalismo. São Paulo, Boitempo. (2015). Os limites do capital. São Paulo, Boitempo.

HILFERDING, R. (1986). O capital financeiro. São Paulo, Nova Cultural.

JAMESON, F. (2001). A cultura do dinheiro. Petrópolis, Vozes.

JESSOP, B. (2007). "Knowlegde as a fictitious commodity: insights and limits of a polanyian perspective". In: BUGRA, A. e AGARTAN, K. Reading Karl Polanyi for the Twenty-First Century: market economy as a political project. Nova York, Palgrave Macmillan.

KEYNES, J. M. (1986). A teoria geral do emprego, do juro e da moeda. São Paulo, Nova Cultural.

LAPAVITSAS, C. (2009). Financialised capitalism: crisis and financial expropriation. Historical Materialism, n. 17, pp. 114-148. Londres, Department of Economics, School of Oriental and African Studies.

LEFEBVRE, H. (2008). Espaço e política. Belo Horizonte, Editora UFMG.

LENIN, V. (1977). Imperialismo, Fase Superior do Capitalismo. Obras Escolhidas, Tomo I. Lisboa, Editorial Avante.

MAGDOFF, H. e SWEEZY, P. (1987). Stagnation and the Financial Explosion. Nova York, Monthly Review Press.

MARX, K. (1986). O capital: crítica da economia política. Livro Terceiro: o processo global da produção capitalista. São Paulo, Nova Cultural.

MINSKY, H. (1982). Can It happen again? Essays on instability and finance. Nova York, M. E. Sharp. 
PAULANI, L. (2009). A crise do regime de acumulação com dominância da valorização financeira e a situação do Brasil. Estudos Avançados. São Paulo, v. 23, n. 66, pp. 25-39.

(2013). Acumulação sistêmica, poupança externa e rentismo: observações sobre o caso brasileiro. Estudos Avançados. São Paulo, v. 27, n. 77, pp. 237-261.

(2016). Acumulação e rentismo: resgatando a teoria da renda de Marx para pensar o capitalismo contemporâneo. Revista de Economia Política. São Paulo, v. 36, n. 3, pp. 514-535.

POLANYI, K. (2012). A grande transformação: as origens da nossa época. Rio de Janeiro, Elsevier.

ROJAS, C. A. A. (2013). Fernand Braudel e as ciências humanas. Londrina, Eduel.

ROLNIK, R. (2015). A guerra dos lugares. São Paulo, Boitempo.

ROUBINI, N. e STEPHEN, M. (2010). A economia das crises: um curso-relâmpago sobre o futuro do sistema financeiro internacional. Rio de Janeiro, Intrínseca.

SANDEL, M. J. (2015). O que o dinheiro não compra: os limites morais do mercado. Rio de Janeiro, Civilização Brasileira.

SANFELICI, D. (2013). Financeirização e a produção do espaço urbano no Brasil: uma contribuição ao debate. Eure. Santiago, v. 39, n. 118, pp. 27-46.

SILVER, B. J. e ARRIGHI, G. (2014). “O duplo movimento” de Polanyi: comparação da hegemonia da belle époque britânica e estadunidense. Emetropolis: Revista Eletrônica de Estudos Urbanos e Regionais, n. 16.

TOPALOV, C. (1991). Os saberes da cidade em crise. Espaço e Debates, n. 34.

WALLERSTEIN, I. (2006). Impensar a ciência social: os limites dos paradigmas do século XIX. São Paulo, Ideias e Letras.

(2011). The modern world-system I: capitalist agriculture and the origins of the european worldeconomy in the sixteenth century. Berkeley, University of California Press.

Texto recebido em 22/dez/2016

Texto aprovado em 27/mar/2017 
